\title{
THE USE OF OIL PALM EMPTY FRUIT BUNCHES COMPOST, RICE HUSK CHARCOAL AND CHICKEN MANURE TO REDUCE NPK FERTILIZER DOSES ON THE GROWTH AND YIELD OF CAULIFLOWER (BRASSICA OLERACEAE VAR. BOTRYTIS L.)
}

\author{
Fitriana Maria*, Sodikin Erizal, Sulaiman Firdaus \\ Department of Agronomy, Faculty of Agriculture, University of Sriwijaya, Indonesia \\ *E-mail: mariafitriana56@yahoo.com
}

\begin{abstract}
The objective of this study was to determine the effects of oil palm empty fruit bunches compost, rice husk charcoal and chicken manure to growth and productivity of cauliflower. This experiment was conducted from July 2019 until October 2019 at Bukit Besar, Palembang, South Sumatra. The design used was Randomized Completely Block Design (RCBD) with 10 treatments and 3 blocks. Each treatment consisted of 3 crops. The treatments were $50 \%$ of NPK fertilizer $\left(P_{1}\right)$, oil palm empty fruit bunches compost 20 ton ha ${ }^{-1}$ $+50 \%$ of $\mathrm{NPK}\left(\mathrm{P}_{2}\right)$, oil palm empty fruit bunches Compost 25 ton ha $+50 \%$ of NPK $\left(\mathrm{P}_{3}\right)$,oil palm empty fruit bunchescompost 30 ton ha $+50 \%$ of NPK $\left(\mathrm{P}_{4}\right)$, rice husk charcoal 20 ton ha ${ }^{-1}$ $+50 \%$ of NPK $\left(\mathrm{P}_{5}\right)$, rice husk charcoal 25 ton ha ${ }^{-1}+50 \%$ of NPK $\left(\mathrm{P}_{6}\right)$, rice husk charcoal 30 ton ha ${ }^{-1}+50 \%$ of NPK $\left(\mathrm{P}_{7}\right)$, and chicken manure20 ton ha ${ }^{-1}+50 \%$ of NPK $\left(\mathrm{P}_{8}\right)$, chicken manure25 ton ha ${ }^{-1}+50 \%$ of $\mathrm{NPK}\left(\mathrm{P}_{9}\right)$, chicken manure30 ton ha ${ }^{-1}+50 \%$ of NPK $\left(\mathrm{P}_{10}\right)$. The result showed thatthe treatment of chicken manure 30 ton ha ${ }^{-1}+50 \%$ of NPK $\left(\mathrm{P}_{10}\right)$ gave the best result on the growth and yield of cauliflower. It was showed by the height of plant, the number of leaves, the age of flowering, the age of harvest, total fresh weight of plantand commercial fresh weight, diameter of stem and diameter of flowers. All of the value of these parameters was highest.
\end{abstract}

\section{KEY WORDS}

Cauliflower, rice husk charcoal, chicken manure, oil palm empty fruit bunches.

Cauliflower is one of favorite vegetables in society and it is important for our health since it contains vitamin and mineral needed by our body. As a result, the demand of this vegetable is increasing (Marliah et al., 2013). Some nutrients in cauliflower are protein, fat, carbohydrate, vitamin, calcium, sodium, niacin, riboflavin, zinc, and glutathione which are highly needed for our health. Amount per $100 \mathrm{~g}$ : Calories 25, total fat $0,3 \mathrm{~g}$, sodium $30 \mathrm{mg}$, potassium $299 \mathrm{mg}$, carbohydrate $5 \mathrm{~g}$, fiber $3 \mathrm{~g}$, sugar $2 \mathrm{~g}$, protein $2 \mathrm{~g}$, calcium $2 \%$, vitamin $\mathrm{C}$ $77 \%$, iron $2 \%$, vitamin B-6 10\%, magnesium 3\% (Szalay, 2018).

According to Cahyono (2001), the cauliflower cultivation prospect is getting higher, and it has high commercial and social values. The demands of cauliflower are also increasing, both in our country and in other countries. Unfortunately, these high demands are not followed by the production enhancement. Cauliflower productivity in Indonesia had decreased since 2013 up to 2017 . The productivity of cauliflower in 2013 was 12.18 ton ha ${ }^{-1}$ and it decreased to 12.08 ton ha $^{-1}$ in 2014. In 2015 it became 10.58 ton ha ${ }^{-1}, 11.91$ ton ha ${ }^{-1}$ in 2016, and kept decreasing to 11.35 ton ha $^{-1}$ in 2017 (Statistics Indonesia, 2018).

To improve the quality and productivity of cauliflower, there are several problems that we should focus on, they are supplying nutrients by giving the plants some fertilizer. Fertilizing is the applying of organic and inorganic chemical substances to improve the soil condition and to fulfil the nutrient need of the plants so it can increase the productivity of the plant (Gomies, 2012). Some of the organic fertilizers which can improve the condition of the soil condition are oil palm empty fruit bunches compost, rice husk charcoal, and chicken manure.

Rice husk charcoal is able to restore the soil structure, to add the soil ability in keeping the nutrients which are good for soil microorganisms and also has characteristic which can keep water and it also is weaker than other media (Agustin et al., 2014). In a study done by 
Mahdiannoor (2011), the use of rice husk charcoal can increase the average height of chili plants with the concentration of 20 ton ha $^{-1}$ or equals to $500 \mathrm{gr}$ per plant for the growth and yield of chili (Capsicum annum).

Another organic fertilizer is oil palm empty fruit bunches compost which contains the nutrients needed by the plant. This fertilizer can reach $23 \%$ of the amount of oil palm waste. Alternatively, the organic fertilizer also gives additional economic benefits (Fauzi et al., 2006). The study done by Eleni (2013) showed that the dosage of oil palm empty fruit bunches compost which can give the best result was at 10 ton $^{-1} \mathrm{a}^{-1}$ with the highest peanut productivity 2.3 ton ha ${ }^{-1}$.

Chicken manure fertilizer can give nutrient contribution which can increase the growth and productivity of plants since this type of fertilizer contains more nutrients than $\mathrm{N}$ content of cow and goat manure (Yuliana, 2015). In the study conducted by Ani (2017), chicken manure fertilizer which were given at the dosage of 35 ton ha ${ }^{-1}$ which equals to 875 gr per plant gave the best result to the plant height, leaf quantity, flower diameter, fresh flower weight, fresh root weight, and dried root weight of cauliflower plant (Brassica oleraceae var. botrytis L). This study was aimed to finding out the effect of the treatment of oil palm empty fruit bunches compost, rice husk charcoal, and chicken manure fertilizer combination with NPK fertilizer toward the growth and yield of cauliflower (Brassica oleraceae var. botrytis $\mathrm{L}$ ).

\section{MATERIALS AND METHODS OF RESEARCH}

This research was conducted at Bukit Besar in Palembang, South Sumatera with the altitude $8 \mathrm{~m}$ above sea level. It started from July until October 2019.

The tools used were hoe, hand sprayer, camera, altimeter, scale, and oven. The materials used were oil palm empty fruit bunches compost, rice husk charcoal, and chicken manure fertilizer, PM 1256 F1 cauliflower seed, soil, pesticide (Curacron and Dithane), seedling polybag, $40 \mathrm{~cm} \times 40 \mathrm{~cm}$ polybag, and Mutiara NPK fertilizer.

This research used Randomized Completely Block Design (RCBD) with 9 treatments and 3 blocks, so there were 27 units of treatments. Each treatment of each block consisted of 3 plants, so the total was 81 crops. The treatments consisted of $50 \%$ of NPK fertilizer $\left(\mathrm{P}_{1}\right)$, 20 tons ha- ${ }^{-1}$ of oil palm empty fruit bunches compost $+50 \%$ of NPK fertilizer $\left(P_{2}\right), 25$ tons ha ${ }^{1}$ of rice husk charcoal $+50 \%$ of NPK fertilizer $\left(\mathrm{P}_{3}\right), 30$ tons ha ${ }^{-1}$ of oil palm empty fruit bunches compost $+50 \%$ of NPK fertilizer $\left(\mathrm{P}_{4}\right), 20$ tons ha ${ }^{-1}$ of rice husk charcoal $+50 \%$ of NPK fertilizer $\left(P_{5}\right), 25$ tons ha ${ }^{-1}$ of rice husk charcoal $+50 \%$ of NPK fertilizer $\left(P_{6}\right), 30$ tons ha ${ }^{-1}$ of rice husk charcoal $+50 \%$ of NPK fertilizer $\left(P_{7}\right), 20$ tons ha ${ }^{-1}$ of chicken manure fertilizer + $50 \%$ of NPK fertilizer $\left(\mathrm{P}_{8}\right), 25$ tons ha $^{-1}$ of chicken manure fertilizer $+50 \%$ of NPK fertilizer $\left(P_{9}\right), 30$ tons ha $^{-1}$ of chicken manure fertilizer $+50 \%$ of NPK fertilizer $\left(P_{10}\right)$. The research included the seedling, planting medium preparation and treatment application, planting, caring, and harvesting.

The parameters observed were plant height, the number of leaves, stem diameter, age of flowering, age of harvest, flower commercial weight, and flower diameter.

\section{RESULTS AND DISCUSSION}

The result of analysis of variance showed that combination treatment of organic fertilizer and NPK fertilizer had significant effect on the plant height and the age of harvest, and very significant effect on the number of leaves, stem diameter, the age of flowering, commercial flower weight, flower diameter.

The result of analysis of variance showed that combination treatment of organic fertilizer and NPK fertilizer had significant effect on the plant height. Regarding the plant height variable, the tallest plant was obtained by $\mathrm{P}_{10}$ treatment ( 30 ton ha ${ }^{-1}$ of chicken manure fertilizer $+50 \%$ of NPK fertilizer) i.e. $13.59 \mathrm{~cm}$ which did not significant difference from $\mathrm{P}_{9}$ treatment ( 25 ton ha $^{-1}$ of chicken manure fertilizer $+50 \%$ of NPK fertilizer) and $\mathrm{P}_{8}$ treatment (20 tons ha $^{-1}$ of chicken manure fertilizer $+50 \%$ of NPK fertilizer) and had significant difference with treatments $\mathrm{P}_{1}, \mathrm{P} 2, \mathrm{P} 3, \mathrm{P} 4, \mathrm{P} 5, \mathrm{P} 6$, and P7. The lowest plant was the one 
which was obtained P6 treatment (25 ton ha ${ }^{-1}$ of rice husk charcoal $+50 \%$ of NPK fertilizer) that was $11.14 \mathrm{~cm}$ (Table 1).

The result of analysis of variance showed that the treatment of the combination of organic and NPK fertilizer had very significant effect towards the number of leaves. The biggest number of leaves was obtained by $\mathrm{P}_{10}$ treatment (30 ton ha ${ }^{-1}$ of chicken manure fertilizer $+50 \%$ of NPK fertilizer) that was 11.89 leaves which were not different significantly from $\mathrm{P}_{9}$ treatment (25 to ha- ${ }^{-1}$ of chicken manure fertilizer $+50 \%$ of NPK fertilizer) but it was different significantly from P1, P2, P3, P4, P5, P6, P7, $\mathrm{P}_{8}$. Additionally, the least leaves was from $P_{2}$ and P4 treatments (20 ton ha ${ }^{-1}$ of oil palm empty fruit bunches compost $+50 \%$ of NPK fertilizer) and (30 ton ha ${ }^{-1}$ of oil palm empty fruit bunches compost $+50 \%$ of NPK fertilizer) that was 9.78 leaves (Table 1 ).

The result of analysis of variance showed that the treatment from the combination of organic and NPK fertilizers had very significant effect on the stem diameter variable. The biggest diameter was from $P_{10}$ treatment (30 ton ha ${ }^{-1}$ of chicken manure fertilizer $+50 \%$ of NPK fertilizer) that was $10.40 \mathrm{~mm}$ which had no significant difference from $\mathrm{P}_{9}$ treatment (25 to ha ${ }^{-1}$ of chicken manure fertilizer $+50 \%$ of NPK fertilizer) but had significant different from P1, P2, P3, P4, P5, P6, P7, $\mathrm{P}_{8}$ treatment, and the smallest was from P5 treatment (20 ton ha ${ }^{1}$ of rice husk charcoal $+50 \%$ of NPK fertilizer) that was $5.74 \mathrm{~mm}$ (Table 1).

The result of analysis of variance showed that the treatment from the combination of organic and NPK fertilizers had very significant effect on the cauliflower age of flowering variable. The fastest blossoming age was from $\mathrm{P}_{10}$ treatment (30 ton ha ${ }^{-1}$ of chicken manure fertilizer $+50 \%$ of NPK fertilizer) that was 30.78 days which had no significant difference from $\mathrm{P}_{9}$ treatment (25 to ha ${ }^{-1}$ of chicken manure fertilizer $+50 \%$ of NPK fertilizer), $\mathrm{P}_{8}$ treatment (20 ton ha- 1 of chicken manure fertilizer $+50 \%$ of NPK fertilizer), $\mathrm{P}_{3}$ treatment ( 25 ton ha ${ }^{-1}$ of rice husk charcoal $+50 \%$ of NPK fertilizer) but had significant difference from $P_{1}, P_{2}, P_{4}, P_{5}, P_{6}$, $\mathrm{P}_{7}$ treatments. The longest blossoming age was from $\mathrm{P}_{5}$ and $\mathrm{P}_{6}$ treatments $\left(20\right.$ ton ha ${ }^{-1}$ of rice husk charcoal $+50 \%$ of NPK fertilizer) and ( 25 ton $^{-1}$ of rice husk charcoal $+50 \%$ of NPK fertilizer) that was 36.22 days (Table 1).

Table 1 - The effect of combination of organic and NPK fertilizers on all observed parameters

\begin{tabular}{cccccccc}
\hline \multirow{2}{*}{ Treatment } & \multicolumn{7}{c}{ Parameter } \\
\cline { 2 - 7 } & $1(\mathrm{~cm})$ & 2 (leaves) & $3(\mathrm{~mm})$ & $4($ days $)$ & $5($ days $)$ & $6(\mathrm{~g})$ & $7(\mathrm{~cm})$ \\
\hline $\mathrm{P}_{1}$ & $11.74 \mathrm{a}$ & $10.22 \mathrm{a}$ & $7.63 \mathrm{a}$ & $35,00 \mathrm{acd}$ & $53,11 \mathrm{a}$ & $94,33 \mathrm{a}$ & $8,50 \mathrm{a}$ \\
$\mathrm{P}_{2}$ & $11.63 \mathrm{a}$ & $9.78 \mathrm{a}$ & $6.26 \mathrm{a}$ & $35,78 \mathrm{ac}$ & $53,78 \mathrm{a}$ & $83,89 \mathrm{a}$ & $8,54 \mathrm{a}$ \\
$\mathrm{P}_{3}$ & $11.87 \mathrm{a}$ & $10.67 \mathrm{a}$ & $7.72 \mathrm{a}$ & $33,00 \mathrm{bd}$ & $52,89 \mathrm{a}$ & $127,00 \mathrm{a}$ & $9,24 \mathrm{a}$ \\
$\mathrm{P}_{4}$ & $11.44 \mathrm{a}$ & $9.78 \mathrm{a}$ & $6.98 \mathrm{a}$ & $35,89 \mathrm{c}$ & $53,33 \mathrm{a}$ & $104,44 \mathrm{a}$ & $9,26 \mathrm{a}$ \\
$\mathrm{P}_{5}$ & $11.43 \mathrm{a}$ & $9.89 \mathrm{a}$ & $5.74 \mathrm{a}$ & $36,22 \mathrm{c}$ & $52,67 \mathrm{a}$ & $76,78 \mathrm{a}$ & $7,50 \mathrm{~b}$ \\
$\mathrm{P}_{6}$ & $11.14 \mathrm{a}$ & $9.89 \mathrm{a}$ & $6.91 \mathrm{a}$ & $36,22 \mathrm{c}$ & $53,44 \mathrm{a}$ & $82,89 \mathrm{a}$ & $8,19 \mathrm{ab}$ \\
$\mathrm{P}_{7}$ & $11.96 \mathrm{ac}$ & $10.00 \mathrm{a}$ & $6.65 \mathrm{a}$ & $35,89 \mathrm{c}$ & $53,33 \mathrm{a}$ & $87,22 \mathrm{a}$ & $8,83 \mathrm{a}$ \\
$\mathrm{P}_{8}$ & $12.79 \mathrm{bc}$ & $10.78 \mathrm{a}$ & $8.55 \mathrm{a}$ & $32,44 \mathrm{~b}$ & $51,44 \mathrm{ab}$ & $151,00 \mathrm{c}$ & $10,31 \mathrm{c}$ \\
$\mathrm{P}_{9}$ & $13.48 \mathrm{~b}$ & $11.22 \mathrm{~b}$ & $9.80 \mathrm{~b}$ & $31,44 \mathrm{~b}$ & $50,56 \mathrm{bc}$ & $192,67 \mathrm{~b}$ & $11,30 \mathrm{c}$ \\
$\mathrm{P}_{10}$ & $13.59 \mathrm{~b}$ & $11.89 \mathrm{~b}$ & $10.46 \mathrm{~b}$ & $30,78 \mathrm{~b}$ & $49,56 \mathrm{bc}$ & $204,22 \mathrm{~b}$ & $11,76 \mathrm{c}$ \\
\hline LSD 0.05 & 1.54 & 0.92 & 1.16 & 2.41 & 2.61 & 29.45 & 1.13 \\
\hline
\end{tabular}

Note:

$P_{1}=50 \%$ of $N, P$, and $K$ fertilizer;

$P_{2}=20$ ton ha ${ }^{-1}$ of oil palm empty fruit bunches compost $+50 \%$ of NPK fertilizer;

$P_{3}=25$ ton ha ${ }^{-1}$ of rice husk charcoal $+50 \%$ of NPK fertilizer;

$P_{4}=30$ ton ha $a^{-1}$ of oil palm empty fruit bunches compost $+50 \%$ of NPK fertilizer;

$P_{5}=20$ ton ha ${ }^{-1}$ of rice husk charcoal $+50 \%$ of NPK fertilizer;

$P_{6}=25$ ton ha ${ }^{-1}$ of rice husk charcoal $+50 \%$ of NPK fertilizer;

$P_{7}=30$ ton ha ${ }^{-1}$ of rice husk charcoal $+50 \%$ of NPK fertilizer;

$P_{8}=20$ ton ha ${ }^{-1}$ of chicken manure fertilizer $+50 \%$ of NPK fertilizer;

$P_{9}=25$ to ha $^{-1}$ of chicken manure fertilizer $+50 \%$ of NPK fertilizer;

$P_{10}=30$ ton ha ${ }^{-1}$ of chicken manure fertilizer $+50 \%$ of NPK fertilizer;

1) plant height, 2) numbers of leaves, 3) stem diameter, 4) age of flowering, 5) age of harvest, 6) commercial flower weight, 7) flower diameter.

The result of analysis of variance showed that the treatment from the combination of organic and NPK fertilizers had significant effect on the age of harvest of the cauliflower. The fastest age of harvest was from $\mathrm{P}_{10}$ treatment $\left(30\right.$ ton ha ${ }^{-1}$ of chicken manure fertilizer $+50 \%$ 
of NPK fertilizer) that was 49.56 days which had no significant difference from $\mathrm{P}_{9}$ treatment ( 25 to ha $^{-1}$ of chicken manure fertilizer $+50 \%$ of NPK fertilizer) and $\mathrm{P}_{8}$ treatment (20 ton ha ${ }^{-1}$ of chicken manure fertilizer $+50 \%$ of NPK fertilizer). The longest age of harvest was from $\mathrm{P}_{2}$ treatment $\left(20\right.$ to ha $^{-1}$ of oil palm empty fruit bunches compost $+50 \%$ of NPK fertilizer) that was 53.78 days (Table 1 ).

The result of analysis of variance showed that the treatment from the combination of organic and NPK fertilizers had very significant effect on the cauliflower commercial flower weight variable. The heaviest commercial flower was from $\mathrm{P}_{10}$ treatment $\left(30\right.$ ton ha ${ }^{-1}$ of chicken manure fertilizer $+50 \%$ of NPK fertilizer) that was $204.22 \mathrm{~g}$ which had no significant difference from $\mathrm{P}_{9}$ treatment ( 25 to ha ${ }^{-1}$ of chicken manure fertilizer $+50 \%$ of NPK fertilizer), and had significant difference from other treatments. The lightest commercial flower was from P5 treatment (20 ton ha ${ }^{-1}$ of rice husk charcoal $+50 \%$ of NPK fertilizer) that was $76.78 \mathrm{~g}$ (Table 1).

The result of analysis of variance showed that the treatment from the combination of organic and NPK fertilizers had very significant effect on the flower diameter variable. The biggest diameter was found from $\mathrm{P}_{10}$ treatment $\left(30\right.$ ton ha ${ }^{-1}$ of chicken manure fertilizer + $50 \%$ of NPK fertilizer) that was $11.76 \mathrm{~cm}$ which had no significant difference from $\mathrm{P}_{9}$ treatment $\left(25\right.$ ton ha ${ }^{-1}$ of chicken manure fertilizer $+50 \%$ of NPK fertilizer) and $\mathrm{P}_{8}$ treatment (20 ton ha ${ }^{-1}$ of chicken manure fertilizer $+50 \%$ of NPK fertilizer) but had significant difference from P5 treatment (20 ton ha ${ }^{-1}$ of rice husk charcoal $+50 \%$ of NPK fertilizer) that was 7.50 $\mathrm{cm}$ (Table 1).

\section{DISCUSSION OF RESULTS}

The results of the study showed that the combination of organic and NPK fertilizers were able to increase the growth and yield of cauliflower. Those could be seen from all observed variables; they were the height of plant, the number of leaves, the age of flowering, the age of harvest, total of commercial fresh flower weight, diameter of stem and diameter of flowers which showed us that treatments had significant and very significant effect on them. $\mathrm{P}_{10}$ treatment (30 ton ha ${ }^{-1}$ of chicken manure fertilizer $+50 \%$ of NPK fertilizer) was the best treatment which gave the highest and the fastest age of flower and harvest. It was presumed that $\mathrm{P}_{10}$ treatment gave optimum nutrients to the cauliflower growth. It was because the combination of chicken manure and NPK fertilizers was able to supply the appropriate and balanced nutrients needed by the plants. Leaves are the part of a plant which contains chlorophyll. As a result, if there is enough nitrogen, the plants become greener and the photosynthesis can be increased.

The chicken manure fertilizer contains Nitrogen three times more than other fertilizers. This nutrient is needed by plants in vegetative phase in forming tissues for example in stem growth which can affect in the plant height. Nurahmi (2010) states that nutrients are important in stimulating the growth of all parts of a plant so it can grow higher. The nutrient absorption relatively happened during the vegetative phase including in increasing the plant height and number of leaves.

It is in line with Mustika et al., (2016) who state that plant will grow well if the nutrients needed are available. It is because chicken manure fertilizer contains optimum nutrients needed by cauliflower growth. These nutrients absorbed by the plants affected the plant weight, the more nutrients were absorbed, the heavier the plants were. It was because plant weight was the result of nutrient accumulation which consisted of carbohydrate, fat, protein which was absorbed by the plants. According to Hartatik et al. (2009), chicken manure fertilizer contains $57 \%$ water, $29 \%$ organic substances, $1.72 \% \mathrm{~N}, 1.82 \% \mathrm{P}, 2.18 \% \mathrm{~K}, 9.23 \%$ Calcium, $0.86 \%$ Magnesium, $6.10 \%$ Manganese. This fertilizer provided optimal place to grow for the plants. Fertile soil made good water absorption and air change possible to happen. $\mathrm{N}$ and $\mathrm{P}$ nutrients which were contained in NPK fertilizer were able to stimulate the plants to grow well. Good soil condition which was accompanied by nutrient availability which came from NPK fertilizer could boost the growth of the plants. N and P nutrients from NPK fertilizer could also boost cell fission that was the meristem cell on the tip of the stem, so the 
plant could grow higher. $\mathrm{N}$ and $\mathrm{P}$ nutrients were the ones which play role in cell fission. This nutrient availability could help the plants in splitting the cell perfectly, so it affected the plant growth. Chicken manure fertilizer made it possible for fertilizer to be absorbed well by the plants because this fertilizer could make it effective for the organisms in fertilizer decomposing process (Lingga, 2003).

\section{CONCLUSION}

Based on the result of the study, it can be concluded that giving 30 ton ha ${ }^{-1}$ of chicken manure fertilizer $+50 \%$ of NPK fertilizer $\left(\mathrm{P}_{10}\right.$ treatment) was the best treatment for the cauliflower growth and yield. It could be seen that all observed variables gave the best result. Giving the chicken manure fertilizer up to 30 ton $^{-1} \mathrm{a}^{-1}$ could decrease the use of NPK fertilizer until $50 \%$ of it. Suggestions that could be given based on this research was to use chicken manure fertilizer as a source of nutrients for cauliflower plants, up to 30 ton ha ${ }^{-1}$ combined with $50 \%$ of NPK fertilizer.

\section{REFERENCES}

1. Agustin, D.A., 2014. The Utilization of Sawdust Waste and Husk Charcoal as Medium for Yellow Cempaka (Michelia champaca). Sylva Lestari Journal. 2(3): 49-58.

2. Ani, R.H. 2017. Effects of Organic and Inorganic Fertilizer Application on Growth and Yield of Cauliflower (Brassica oleraceae var. botrytis L.) (Thesis), Agriculture Faculty, University of Sriwijaya. Indralaya.

3. Cahyono, B. 2001. Cauliflower and Brocoli. Cultivation Technic and Analysis of Farming Business. Kanisius, Yogyakarta.

4. Damanik, M.B. 2011. Soil Fertility and Fertilizer. University of North Sumatera, Medan.

5. Eleni, W. 2013. Effects of Oil Palm Empty Fruit Bunches Compost on Growth and Yield of Peanut. Agriculture Faculty, University of Sriwijaya. Indralaya.

6. Gomez, K.A., and A.A. Gomez. 1995. Statistical Procedures for Agricultural Research. Translated by Endang, S., and Justika, S.B. 1995. University of Indonesia Press. Jakarta.

7. Gomies, L. 2012. Effects of Liquid Fertilizer Ril on Growth anf Yield of Cauliflower (Brassica oleraceae var. botrytis L.). Agriculture Faculty, University of Patimura. Agrologia Journal. 1 (1): 13-20.

8. Gomez, K.A., and A.A. Gomez. 1984. Statistical Procedures for Agricultural Research. John Wiley \& Sons, New York.

9. Hartatik, W. Simanungkalit, 2006. Organic Fertilizer and Biological Fertilizer. Research and Development Center for Agricultural Land Resources. Bogor.

10. Lingga, P. 2003. The instructions for use of fertilizer. Penebar Swadaya. Jakarta.

11. Marliah, A. 2013. Effects of Variety and Concentration of Compound Fertilizer on Growth and Yield of Cauliflower (Brassica oleraceae L.) Floratek Journal. 8: 118-126.

12. Mahdiannoor. 2011. Response of Growth and Yield of Big Chili (Capsicum annum L.) to Application of Husk Charcoal and Duck Manure Fertilizer Doses in a Swamp Land. Agroscientiae Journal. 18 (3): 166-167.

13. Mustika, S., K. Pasigai, A. Wahyudi. 2016. Effects of Chicken Manure Fertilizer on Growth and Yield of Cauliflower (Brassica oleraceae var. botrytis L.) on Oxic Dystrudepts Lembantongoa. Agrotekbis E-journal. 4 (2): 151-159.

14. Nurahmi, E. 2010. Growth and Yield of Cauliflower Due to the Application of Liquid Organic Fertilizer Nasa and Hormone Growth Regulator. Agriculture Faculty, University of Syiah Kuala Darussalam. Banda Aceh.

15. Statistics of Indonesia. 2018. Ministry of Agriculture Directorate General of Horticulture.

16. Szalay, J. 2018. Cauliflower: Health Benefits \& Nutrition Facts. Retrieved on November 27, 2019 from http://www.livescience.com

17. Yuliana, Y., Rahmadani, E., and Permatasari, I. 2015. Application of Cow Manure Fertilizer and Chicken Manure Fertilizer on Growth and Yield of Gingger (Zingiber officinale ) at Peat Land. Agrotecnology Journal, 5(2): 37-42. 